www.nature.com/ijo

\title{
CORRIGENDUM
}

\section{Variants of the interleukin-1 receptor antagonist gene are associated with fat mass in men}

N Andersson, L Strandberg, S Nilsson, Ö Ljungren, M K Karlsson, D Mellström, M Lorentzon, $\mathrm{C}$ Ohlsson and J-O Jansson

International Journal of Obesity (2009) 33, 703; doi:10.1038/ijo.2009.58

Correction to: International Journal of Obesity (2009) 33, 525-533; doi:10.1038/ijo.2009.47; published online 17 March 2009

Since the publication of the above paper, the authors have noticed that the Conclusions section in the abstract is wrong.

The Conclusions should read:
The ILIRN gene, shown to enhance obesity by suppressing IL-1 effects in experimental animals, has not previously described gene polymorphisms and haplotypes that are associated with fat, but not lean mass in two populations of men.

The authors would like to apologize for the error. 